\title{
Endodontik Tıp: Sistemik Hastalıkların Pulpal ve Periapikal Dokular ile İlişkisi
}

\section{Endodontic Medicine: The Relation of Systemic Diseases with Pulpal and Periapical Tissues}

\author{
Jülide OCAK ${ }^{1 *} \odot$, Ayșe Diljin KEÇECỉ1 1
}

1Süleyman Demirel Üniversitesi, Diș Hekimliği Fakültesi, Endodonti Anabilim Dalı; Isparta, Türkiye

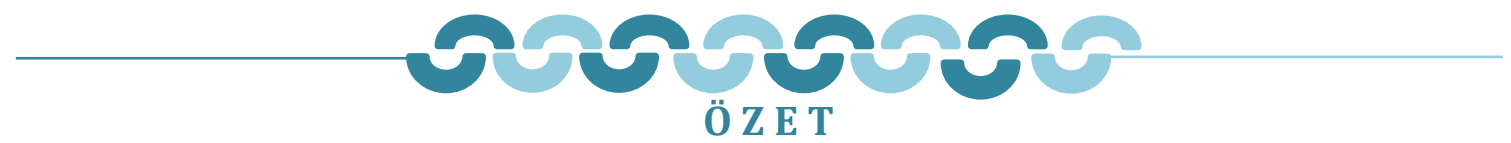

Apikal periodontitis, enfekte kök kanal sisteminin periapikal dokularda meydana getirdiği kronik enflamatuar bir hastalıktır. Tedavi edilmeyen pulpitis ve kök kanal sistemi içerisinde bulunan çeşitli mikroorganizmaların kolonizasyonu, ilgili dişlerde pulpa nekrozuna ve periapikal bölgede enflamatuvar hastalık gelişimine yol açar. Apikal periodontitis lokal bir patolojik değişiklik olarak kabul edilse de, diyabet ve kardiyovasküler hastalıklar da dahil olmak üzere, olumsuz sistemik etkilerinin olduğu düşünülmektedir. Araştırmacılar yarım yüzyıldan fazla bir süredir, lokalize bir ağız enfeksiyonu olarak apikal periodontitisin sistemik immün yanıtı bozup bozmadığını ve genel sağlık durumu tehdit edip etmediğini araștırmaktadırlar. Endodontik enfeksiyonlar ile sistemik hastalıklar arasındaki çift yönlü ilişkiyi ele alan "Endodontik Tıp", literatürde oldukça yenidir ve her geçen gün daha fazla önem kazanmaktadır. Sistemik hastalıklar endodontik enfeksiyonların patogenezini etkileyebilirken, endodontik enfeksiyonun da sistemik etkileri olabileceğini gösteren çok sayıda kanıt vardır. Diyabet, kardiyovasküler hastalıklar, renal ve romatoit hastalıklar ve hipoöstrojenemi gibi sistemik hastalıkların pulpa ve periodonsiyumda yarattıkları değişiklikler incelenmektedir. $\mathrm{Bu}$ değişiklikler, periapikal bölgede daha şiddetli bir kemik rezorpsiyonu ve enflamasyonun yanı sıra sistemik hastalığın ilerlemesi șeklinde de olabilir. 1800'lerden 1950'lere kadar oral enfeksiyonun sistemik hastalıkla direkt ilişkisini savunan fokal enfeksiyon teorisi nedeniyle diş ve tonsilla gibi organların uzaklaştırılması öneriliyordu. Bu durumun daha sonra kesin bir dil ile reddedilmesine karșın, yeni çalışmalar ıșığında sistemik ve pulpal ilişkinin keskin sınırlarla ayrılamayacağı anlașılmaktadır. Bu derlemenin amacı, sistemik hastalıklar ile endodontik enfeksiyon ve kök kanal tedavisi sonuçlarının arasındaki çift taraflı ilişkiyi ortaya koyan en güncel literatürü analiz etmek ve bu bağlantıların sistemik sağlık durumu ile endodontik tedavi sonuçlarına nasıl etki edebileceğini belirlemektir.

Anahtar Kelimeler: Endodontik tıp, sistemik hastalıklar, apikal periodontitis, kök kanal tedavisi.

Alınış / Received: 24.03.2021 Kabul / Accepted: 06.08.2021 Online Yayınlanma / Published Online: 15.08..2021

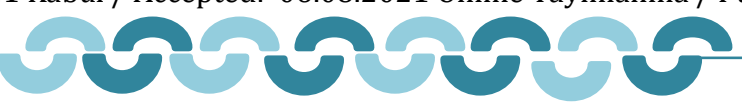

A B S T R A C T

Apical periodontitis is a chronic infection that occurs in the periapical tissues within the root canal system. Untreated pulpitis and colonization of various microorganisms in the root canal system can lead to pulpal necrosis and inflammatory disease in the periapical region of the involved teeth. Although apical periodontitis is generally considered a local pathological change, numerous studies have attempted to evaluate whether it is associated with the development of adverse systemic health conditions, including diabetes and cardiovascular disease. For more than half a century, studies have been investigating whether apical periodontitis, as a localized oral infection, impairs the systemic immune response and threatens general health.

"Endodontic Medicine", which deals with the bidirectional relationship between endodontic infections and systemic diseases, is quite new in the literature and is gaining more and more importance day by day. While systemic diseases may affect the pathogenesis of endodontic infections, there is ample evidence that endodontic infection may also have systemic effects. The changes in the pulp and periodontium caused by systemic diseases such as diabetes, cardiovascular diseases, renal and rheumatoid diseases and hypoestrogenemia have been examined. These changes may be in the form of more severe bone resorption and inflammation in the periapical region, as well as progression of systemic disease. From the 1800 s to the $1950 \mathrm{~s}$, it was recommended to remove organs such as teeth and tonsils due to the focal infection theory, which advocated a direct relationship between oral infection and systemic disease. Although this situation was rejected outright later, it has been understood that the systemic and pulpal relationship cannot be separated with sharp boundaries in the light of new studies. The purpose of this review was to analyze the most recent literature revealing the bilateral relationship between systemic diseases and endodontic infection and root canal treatment outcomes, and to determine how these links may affect systemic health status and endodontic treatment outcomes.

Keywords: Endodontic medicine, systemic diseases, apical periodontitis, root canal treatment. 


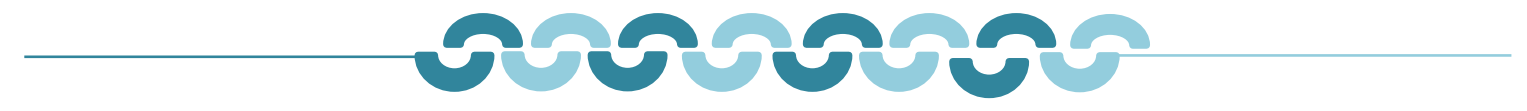

\section{Giriş}

Oral enfeksiyonlar ile sistemik hastalıklar arasındaki ilişkiyi hedef alan Endodontik Tıp kavramı, neredeyse milattan dörtyüz yıl öncesine dayanmaktadır. 0 dönemde Hipokrat, ağızda odontojenik enfeksiyon kaynağı olarak görülen şüpheli dişlerin çekilmesinden sonra romatoid artrit bulgularının gerilediğini bildirmiștir (1). 1891 yılında Miller, odontojenik olmayan enfeksiyonlar da dahil olmak üzere, birçok sistemik hastalığın oral mikroorganizma varlığından kaynaklandığını açıklamış ve ilgili dişlerin çekilmesinden ziyade enfekte kök kanallarının tedavi edilmesini önermiştir (1). Öte yandan İngiliz cerrah William Hunter, meydana gelen oral enfeksiyon ve oral sepsis olgularını kolit, anemi ve gastrit gibi birçok hastalığın gelişiminden sorumlu tutarak, operatif diş hekimliğini eleştirmiştir. İnsanların endodonti bilimini sorgulamaya başladığı o dönemlerde, enfeksiyon odağı oluşturmamak adına pulpası vital olmayan tüm dişlerin çekildiğinden ve milyonlarca bademcik ve adenoidin cerrahi olarak çıkartıldığından bahsedilmektedir (1). Yakın zamanlarda Chicago'da bulunan Frank Billings, tonsillektomi ve diş çekimleri neticesinde uzak doku enfeksiyonlarının iyileștiğini iddia etmiştir (1). Hunter'ın ortaya attığı oral sepsis terimi, bundan sonra "fokal enfeksiyon" adı altında anılmaya başlamıştır (1).

Bugünkü bilgiler ışı̆̆ında endodontik tedavinin nihai amacının, kök kanalında enfeksiyon gelişmesinin önüne geçerek, apikal periodontitis oluşumunu önlemek veya ortadan kaldırmak olduğu söylenebilir. Kök kanal sistemi periradiküler enfeksiyonların yanı sıra, sistemik hastalıkların prognozunu etkileyen veya oluşumuna sebep olan bazı mikrobiyal toplulukları içinde barındıran bir rezervuar görevi görebilmektedir. Son çalıșmalara göre bazı sistemik durumların da endodontik patobiyolojiyi değiştirecek önemli etkilere sahip olduğu sonucuna varılmıştır (2-6). Birçok çalışma, periodontal hastalık ile sistemik durum ve hastalıklar arasındaki ilişkiyi yeniden gündeme taşımıştır (7-10). Aradaki bağlantıyı yakından incelemek üzere çalışan periodontal tıp, periodontal patojenlerin etiyopatolojik anlamda önemli rol oynadıklarını bilimsel olarak kanıtlamış olsa da, kronik sistemik hastalıkların multifaktöriyel doğası ile doğrudan bir sebep-sonuç ilişkisi kuramamıştır (8). Apikal periodontitis ile periodontal hastalıklar, etki gösterdikleri dokular açısından, etiyoloji ve patogenez mekanizmaları farklı olsa dahi fizyopatolojik olarak önemli benzerliklere sahiptir (11). Her ikisi de gram negatif anaerobik bakteri ağırlıklı, büyük bir mikrobiyotayı paylaşan, kronik ve polimikrobiyal enfeksiyonlardır (11). Periodontal hastalıklar ile ilişkisi kanıtlanmış sistemik bozuklukların, benzer şekilde apikal periodontitis ile ilişkili olduğunu varsayarak "periodontal tıp" ile aynı yolu izleyen "endodontik tıp" terimi geliștirilmiștir $(11,12)$.

$\mathrm{Bu}$ derlemenin amacı, sağlık ve hastalık durumundaki pulpa ve periapikal dokular ile sistemik durum arasındaki çift yönlü ilişkiyi tartışmaktır. Pulpa ve periapikal hastalıkların sistemik sağlı̆̆a etki etmelerinin yanı sıra, sistemik hastalıkların da pulpa ve periapikal dokular üzerinde etkileri bulunmaktadır (12).

\section{Diabetes Mellitus (Diyabet)}

Diabetes mellitus (diyabet) insülin yapımı, salımı ya da insülin etkisinde bir bozukluk nedeniyle ortaya çıkan, hiperglisemi ile karakterize başlıca karbonhidrat, lipid ve protein metabolizmasını etkileyen kronik bir hastalıktır. Diyabetin apikal periodontitis patogenezi üzerindeki etkisini tanımlayan ilk makalede, Kohsaka ve ark. diyabetik sıçanlarda, periapikal bölgedeki periodontal ligament enflamasyonu ile birlikte kök ve alveoler kemik rezorpsiyonunun daha şiddetli seyrettiğini göstermiştir (13). Kontrol grubu ile karşılaştırıldığında, periapikal bölgedeki lezyonların diyabetik sıçanlarda daha büyük olduğu izlenmiștir. Diyabetik sıçanlar ile normoglisemik kontrol grupları arasındaki iltihaplanma ve periapikal kemik kaybının şiddetini karşılaştıran diğer hayvan çalışmalarında da benzer sonuçlar rapor edilmiştir (14).

Gupta ve ark. (2020), diabetes mellitus ile kök kanal tedavili dişlerdeki periapikal lezyon prevalansı arasındaki ilişkiyi değerlendirmek amacıyla, diyabetik ve diyabetik olmayan hastalardan alınan kök kanal tedavisi sonuçlarını, radyolüsent periapikal lezyonların varlığı açısından karşılaştırarak, mevcut klinik literatürü analiz etmiştir. Bu konuyla ilgili sınırlı prospektif klinik çalışma bulunmasına rağmen, havuzdaki veriler, diyabetikler ile kök kanal tedavili dişlerdeki periapikal radyolüsensi varlığı arasında güçlü bir bağlantı olduğunu ortaya koymuştur (15). 
Şekil 1: Periapikal Durum ile Diyabet İlişkisi; Kronik periapikal enflamasyon doğal bağışıklık sisteminin geniş kapsamlı aktivasyonunu içermektedir. Apikal periodontitis etkeni olarak bilinen gram negatif anaerobik bakterilerden köken almış lipopolisakkarit (LPS), immün hücrelerde bulunan spesifik reseptörlere bağlanarak intraselüler yolakları aktive eder. Bunlardan özellikle transkripsyon faktörü NFКB (nuclear factor kappa-light-chain-enhancer of activated B cells), pro-enflamatuvar sitokin seviyelerini artırarak diyabet hastalarında görülen pro-enflamatuvar sistemik durumu etkiler. İmmün hücreler, endotel hücreleri, yağ hücrelerinde (adipositlerde), pankreas, karaciğer ve kas hücrelerinde gerçekleşen bu enflamatuvar yolakların aktivasyonu toplam insülin direncinde artışa neden olarak, hem Tip 2 diyabet hastası olup hem de kronik apikal periodontitise sahip kişilerde metabolik kontrolü değiştirir. AGE (Advanced glycation end products)'ler makrofajlar üzerindeki RAGE (Receptor for AGE) reseptörlerine bağlanarak ayrıca NF-kB aktive etmekte ve viköz döngüyü sonlandırır (3).

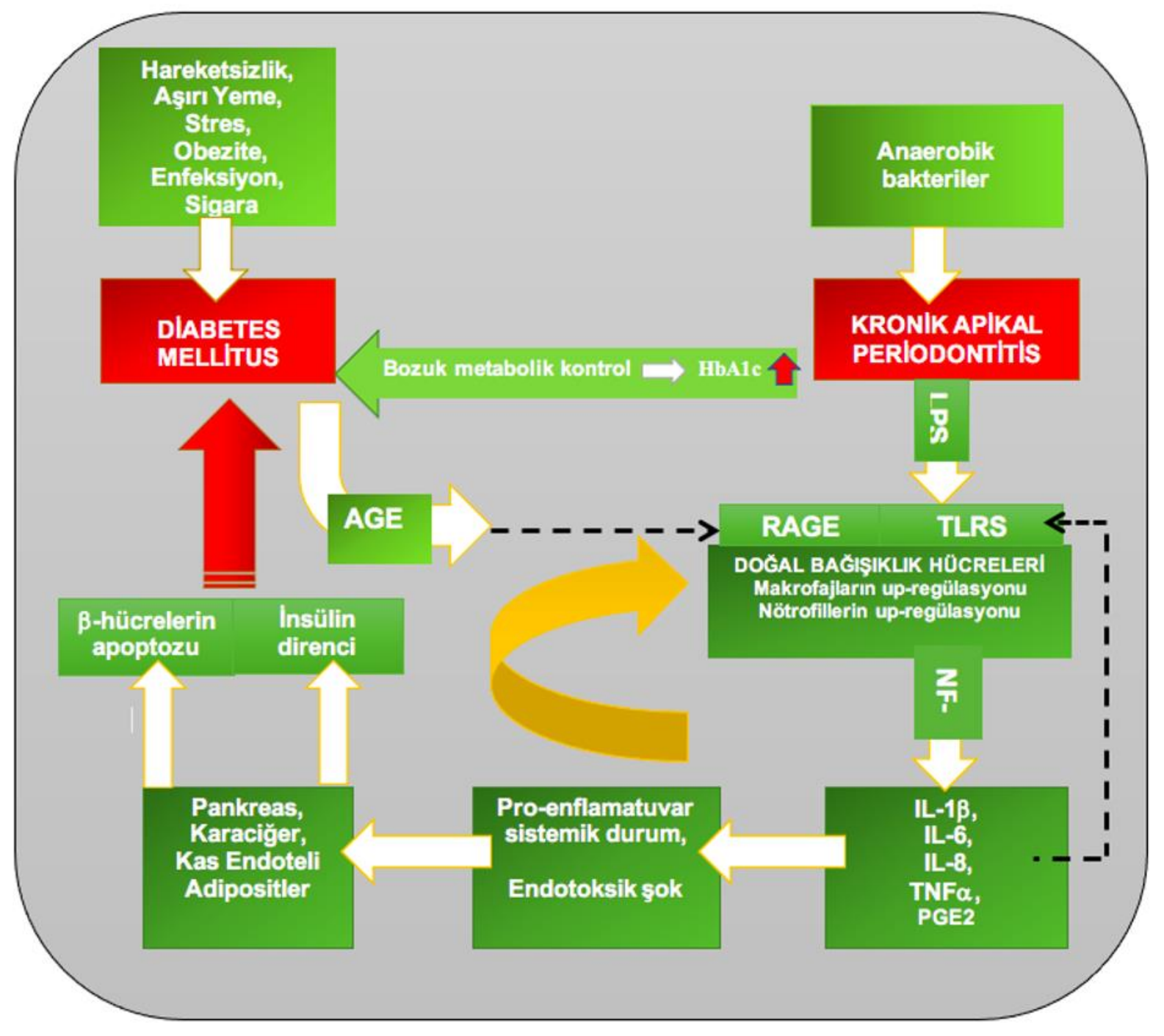

Aydın ve ark. (2021) kök kanal tedavisi öncesi enfeksiyon sonucu hasar gören periapikal kemik trabekülasyonundaki kantitatif değişimi tip 2 diyabet hastalarında fraktal analiz kullanarak değerlendirmişler, kanal tedavisi sonrası fraktal boyut artışının tip 2 DM hastalarında sağlıklı bireylere klyasla daha düşük olduğunu bildirmişlerdir (16).

İnsan çalışmalarında diyabetin apikal periodontitis ile iliş̧isi apikal periodontitis sıklı̆̆ı, kök kanal tedavisi sıklığı ve kök kanal tedavisi başarısı olmak üzere üç temel endodontik değişken altında incelenmiştir. Kök kanal tedavisi başarısı, lezyonlu veya lezyonsuz kök kanal tedavili dişlerin oranı veya kanal tedavisinden sonra yapılan çekimlerin oranı hesaplanarak belirlenmiştir (17-20). 
Birçok insan çalışması apikal periodontitis prevalansı ile diyabet arasındaki korelasyonu incelemiştir (Şekil 1). Segura-Egea ve ark. 38 diyabetik ve 32 normoglisemik hastanın kayıtlarını kullanarak yaptıkları retrospektif bir çalışmada, diyabet grubunun $\% 81,23$ 'ünde, kontrol grubunun ise $\% 58$ 'inde en az bir dişte olmak üzere apikal periodontitis varlığını tespit etmişlerdir (17). Araştırmacılar, tip 2 diyabetin artmış apikal periodontitis prevalansı ile anlamlı derecede ilişkili olduğunu savunmuştur. Daha sonra, LópezLópez ve ark., 50 diyabetik ve 50 normoglisemik hastanın radyografik değerlendirmesi ile kesitsel bir çalışma gerçekleştirmiş; bunun sonucunda diyabetik hastaların \%74'ünde, normoglisemik hastaların ise yalnızca \%42'sinde, bir veya daha fazla dişte apikal periodontitis varlığına rastladıklarını bildirmişlerdir (18). Ayrıca, Dinç (2016), tedavi edilmemiş apikal periodontitis prevalansının kontrolsüz (HgA1c $\geq 6$ ) tip 2 diyabet hastalarında anlamlı oranda daha fazla olduğunu göstermiştir (19). Buna göre diyabet, primer endodontik enfeksiyona yatkınlığı artırarak, apikal periodontitis patogenezinde modifiye edici bir rol oynamaktadır. Diabetes mellitus hastalarında artmıș apikal periodontitis prevalansı ile birlikte persiste kronik apikal periodontitis prevalansının da artmış olduğu gösterilmiştir $(19,20)$. Taç $(2008)$, diyabetik hastalardan izole edilen kök kanal florası kültür ve PCR yöntemleriyle incelenmiş; apikal periodontitsli dişlerde diyabetin kontrol düzeyi (HgA1c) azaldıkça Gram pozitif mikroorganizmaların sayısının anlamlı düzeyde arttığı, nekrotik dişlerde ise dişlerde ise diyabetin kontrol düzeyi azaldıkça Gram negatif mikroorganizmaların anlamlı düzeyde arttığı bildirilmiștir. Yine diyabetli bireylerde sağlıklı bireylerden anlamlı düzeyde fazla mantar türü izole edilmiştir (20).

Apikal periodontitis sıklığının yanı sıra, diyabetik ve kontrol grubundaki deneklerin kök kanal tedavisi sıklığı da incelendiğinde anlamlı bir fark olmadığını ortaya koyan çalışmaların $(17,21)$ aksine, diyabet hastalarındaki artmış kök kanal tedavisi sıklığını rapor eden çalışmalar da dikkat çekmektedir $(18,19)$.

Diyabet ayrıca endodontik başarının anlamlı derecede azalmasıyla ilişkilendirilmiştir (22). Kök kanal tedavisinden sonraki persiste apikal periodontitis sıklı̆ı tip 2 diyabet hastası olan erkeklerde daha fazla bulunmuştur (23). Özellikle de glisemik kontrolü zayıf bireylerin endodontik başarısızlık ile ilişkilendirilmesine karşın bazı araştırmacılar tarafından bu ilişkiyi kanıtlayabilecek kadar yeterli sayıda literatürün bulunmadığı da savunulmaktadır (24). Bir sistematik inceleme ve meta-analiz raporuna göre diyabet, kök kanal tedavisi için önemli bir pre-operatif prognostik faktör olarak kabul edilmelidir (25). Diyabetik ve diyabetik olmayan hastaların postoperatif 12 aylık takibi süresince periapikal skorlamada anlamlı bir azalma gözlemlenmesine karşın, diyabetik hastalarda (\%43) periapikal iyileşmenin kontrol grubuna (\%80) klyasla anlamlı ölçüde daha az olduğu görülmüştür (26).

Sarmento ve ark. (2020), diyabetik ve normoglisemik bireylerin apikal periodontitis lezyonlarında yer alan RANK, MMP-9 ve PTHrP biyobelirteçlerin immünoekspresyonunu karşılaştırmıștır. Analiz edilen kemik rezorpsiyon medyatörlerinin, diyabetik ve normoglisemik bireylerin periapikal lezyonlarında benzer immünoekspresyona sahip olduğu bulunmuş, bu durum diyabetik hastalar tarafından idame edilen etkin glisemik kontrolün, kemik rezorpsiyonundaki artışı önlediği yönünde açıklanmıştır (27).

Fouad ve Burleson (2003) tedavi sonrası iki yll süreyle takip ettikleri diyabetik hastalarda, insüline bağımlı diyabetiklerin artmış semptomatik periradiküler hastalıklara, geri kalan tüm diyabetiklerin de akut endodontik alevlenmelere yatkın olduklarını gözlemlemiştir (22). Endodontik-periodontal lezyonların alevlenmesi ile doğru orantılı olarak kan glikoz seviyesinin arttı̆̆ını gösteren bir olgu raporunda, kombine lezyonların alevlenmesini takiben yapılan kök kanal tedavisinden sonra diyabet kontrolü için gerekli insülin miktarı, hastalık öncesi miktar ile ancak kırk gün sonra eşit hale gelebilmiştir (28).

Saghiri ve ark. (2021), tip 1 ve tip 2 diyabet hastalarında döner eğe kullanıldığında kaldırılan dentin miktarının diyabetik olmayan dentin örneklerine kıyasla daha fazla olduğunu bulmuşlardır. Buna göredöner aletlerin dentine artan penetrasyonu ile prosedürel kazaları artabileceğive diyabetik hastalarda kanal tedavili dişlerin zayıflamasına yol açabileceği öngörülmüştür (29).

Sarmento ve ark. (2020), diyabetik ve normoglisemik bireylerin apikal periodontitis lezyonlarında yer alan RANK, MMP-9 ve PTHrP biyobelirteçlerin immünoekspresyonunu karşılaştırmıștır. Analiz edilen kemik rezorpsiyon medyatörlerinin, diyabetik ve normoglisemik bireylerin periapikal lezyonlarında benzer immünoekspresyona sahip olduğu bulunmuş, bu durum diyabetik hastalar tarafından idame edilen etkin glisemik kontrolün, kemik rezorpsiyonundaki artışı önlediği yönünde açıklanmıştır (27). 


\section{Kardiyovasküler Hastalıklar}

Kardiyovasküler hastalık ile endodontik enfeksiyon arasındaki bağlantıyı büyük oranda CRP (C-Reaktif Protein) oluşturmaktadır. CRP, bir pozitif akut faz proteinidir. Enflamatuvar uyaranları takiben konsantrasyonu arttığı için hem enflamasyon hem de kardiyovasküler risk belirteçi olarak kullanılır (30). Apikal periodontitis veya endodontik tedavi ile kardiyovasküler hastalıklar arasındaki ilișkiyi zayıf olarak nitelendiren çalışmalar dışında (31-33) hem lokal hem de sistemik enflamatuvar etkilerinin olduğunu gösteren çok sayıda çalışma mevcuttur (34). Bununla ilgili olarak Proctor ve ark., dental pulpadaki CRP artışını CRP plazma konsantrasyonundan bağımsız, lokal bir artış olarak değerlendirmişlerdir (35). Ancak, bazı çalışmalar uzun süreli kronik apikal periodontitis lezyonların plazmatik CRP seviyelerinde hafif bir artışa neden olduktan sonra; endodontik tedavi ve periradiküler cerrahiden sonraki üçüncü ayda tekrardan düşüş izlendiğini göstermiştir (36). Bunun gibi, akut alveolar apse olgularında da başta yüksek olan sistemik CRP düzeyleri, endodontik tedaviden bir hafta sonra anlamlı derecede azalmıștır (37). CRP plazma seviyesi, IL-6 ve fibrinojen düzeyleri kronik apikal periodontitis ile olduğu gibi vücut kitle indeksi ile de iliş̧ili bulunmuştur (38). Bu biyobelirteçlerin uzun süre yüksek seviyede seyretmesi, kardiyovasküler bir risk ile de ilişkilendirilmektedir (38).

1986-2000 yılları arasında on binlerce sağlık çalışanını kapsayan bir çalışmada kök kanal tedavisi ile kardiyovasküler hastalıklar arasında iki veya ikiden fazla kök kanal tedavili dişe sahip erkeklerde, hiç kök kanal tedavisi yapılmamış erkeklere göre güçlü; 56 yaşından küçük erkeklerde veya sigara kullananlarda daha güçlü bir iliş̧i bulunmuştur. En güçlü ilişki ise hem sigara kullanan hem de iki veya ikiden fazla dişte kanal tedavisi olan kişilerde görülmüştür (39). Sonuç olarak, kardiyovasküler hastalık açısından ağızdaki kök kanal tedavili diş sayısının ve sigara kullanımının genç yaştaki erkekler için birer risk faktörü olabileceği bulunmuştur (39).

Hipertansiyonun kemikte kalsiyum kaybına ve buna bağlı olarak mineral yoğunluğunda azalma gibi bazı metabolik değişikliklere yol açtı̆̆ı bilinmektedir. Cosme-Silva ve ark. hipertansif sıçanlarda gri ve beyaz MTA gibi bazı kalsiyum silikat esaslı materyal kullanımının, aşırı enflamatuvar yanıt ve düşük bir mineralizasyon oranı ile sonuçlandığını gözlemlemişlerdir (33). Endodontik enfeksiyonların kardiyovasküler sistemde endotel hasarına yol açtığı ileri sürülmüş olsa da (30), endodontik parametreler ile aralarında herhangi bir ilişki olduğu kanıtlanamamıştır (11).

Messing ve ark. tarafından KCNK3 genindeki bir polimorfizme bağlı hipertansiyon ile apikal periodontitis arasında bir iliş̧ki eğilimi bulunmuştur (40). KCNK3 geni potasyum kanal proteinlerini kodlayan bir gendir; fonksiyon kaybına yol açan mutasyonların meydana gelmesi kalıtımsal ve idiyopatik pulmoner arteriyel hipertansiyon, sonrasında sağ ventrikül yetmezliği ve ölüm ile sonuçlanabilmektedir.

Jakovljevic ve ark. (2020) kardiyovasküler hastalıklar ile apikal periodontitis arasında zayıf bir ilişkinin var olduğu sonucuna varmışlardır (6). Öncesinde yapılan sistematik incelemeler, kardiyovasküler hastalıklar ve apikal periodontitisin, sigara ile ilişkili olduğunu bildirmişlerdir $(41,42)$. Aynı şekilde genetik yatkınlık da, hem kardiyovasküler hastalıklar $(43,44)$ hem de apikal periodontitis $(6,45)$ gelişimi açısından bazı çalışmalar tarafından önemli bulunmuştur. Bu bağlamda, immün yanıtta rol oynayan genetik molekülleri ile alakalı polimorfizmler, kardiyovasküler hastalıklara olan yatkınlığı artırdığı gibi apikal periodontitise duyarlılığı artırabilir veya periapikal patolojinin onarımını geciktirebilir.

Lipit profili ve karotid arter intima media kalınlığı ölçümü ile apikal periodontitis ve ateroskleroz arasındaki ilişkiyi araştıran başka bir hayvan çalışması, apikal periodontitisin trigliserit düzeylerini ateroskleroz yokluğunda bile artırdığını ve karotid arter intima medaidaki kalınlık artışını etkilediğini göstermiştir. Ateroskleroz, periapikal lezyondaki enflamatuar reaksiyonu yoğunlaştırmış ve kemik rezorpsiyonunu artırmıştır (46).

\section{Hamilelik}

Bakteriyel enfeksiyonların yol açtı̆̆ı oral enflamasyonlar, sistemik dolaşıma karışarak fötoplasental yapıya ulaşabilen bakteri ve enflamatuvar medyatörler içermektedir (47). Buna ilişkin generalize periodontitis hastası gebelerin amniyotik sıvı ve subgingival plak örneklerinde, periodontal patojenlere rastlanmıştır (48). Çalışmalar, maternal periodontal hastalık ile düşük doğum ağırlığı, erken doğum ve intrauterin gelişim geriliği arasında bir ilişki göstermiştir (48). Ayrıca, apikal periodontitis hastası anne köpeklerden doğan yavru köpeklerin beyin dokularında kontrol grubuna kiysala daha yüksek 
konsantrasyonda TNF-a tespit edilmiştir (49). Yüksek TNF-a konsantrasyonu ise insülin direnci ile ilişkilendirilmiştir (49).

Persiste endodontik enfeksiyona sahip bir hastadan izole edilen Porphyromonas gingivalis'in fare pulpasına inokülasyonunu takiben, mikroorganizmanın plasentaya translokasyonu, anne farede sistemik enflamasyon ve erken doğum gerçekleşmiştir (50). Vaka kontrol çalışmalarında erken doğum yapan annelerin \%54'ünde en az bir diște apikal periodontitis varlığı bildirilmiştir (51). Sonuç olarak, maternal apikal periodontitis prevalansının artması ile birlikte insülin direnci ile tip2 diyabet, Alzheimer ve Parkinson gibi sistemik değişiklikler ve hastalıklar meydana gelebilmektedir (52).

Şiddetli periodontitis olumsuz gebelik sonuçları açısından yeni bir risk faktörü olarak kabul edilmektedir $(53,54)$. Bu ilişki, her iki durumun da mikrobiyal enfeksiyonlar ve artan lokal ve sistemik enflamatuar medyatör seviyeleri ile ilişkili olması ile açılanmaktadır. Bu bağlamda, sistematik incelemelerden elde edilen tutarlı kanıtlar, periodontal sağlığın idame edilemediği hamile kadınlarda preeklampsi (55) ve erken ve/veya düşük ağırlıklı doğum riskinin yüksek olduğunu göstermektedir $(56,57)$.

Apikal periodontitis durumunda hamile kadınlar, periapikal enfeksiyonu olmayan kadınlara göre önemli ölçüde daha kısa bir gebelik süresi geçirmiş olmakla beraber, doğum oranı daha düşük ve neonatal uzunluk ve baş çevresi daha kısa bebekler doğurmuşlardır. Periapikal enfeksiyona sahip gebelerde erken doğum insidansı $(\% 10,0)$ periapikal enfeksiyonu olmayan kadınlara göre daha yüksek bulunmuștur $(57$, 58).

\section{Hipoöstrojenemi}

Hayvan çalışmaları göstermiştir ki, ooferektomi işlemi ile sağlanan östrojen düşüklüğü (hipoöstrojenemi) periapikal lezyon büyüklügünde, proenflamatuvar sitokin ve matriksmetalloproteinaz ekspresyonunda artışa neden olmaktadır $(59,60)$. Östrojen düşüklüguünün alveol kemiğindeki osteositlerde otofajiyi azaltarak, osteosit apoptozunu artırdığı görülmüştür (59). Hipoöstrojenemik koşullar altında osteoklastogenez ve osteoklast aktivitesinin tetiklendiği, RANKL değerlerinin ve enflamatuvar hücre infiltratının arttığı rapor edilmiştir (60).

Silva ve ark. (2019), alendronatın (ALN) yumurtalıkları alınmış sıçanlarda indüklenen periapikal lezyonların gelişimi üzerindeki etkisini değerlendirmişlerdir (61). Ooferektominin neden olduğu hipoöstrojenik durum, kemik erimesini şiddetlendirerek osteositlerin ölümünü indüklemiş ve daha büyük periapikal lezyonların oluşmasına izin vermiştir. ALN tedavisi, ooferektomize sıçanların periapikal lezyonlarında kemik rezorpsiyonunu inhibe ederek, IL-6 yoluyla osteosit apoptozunu ve enflamasyonu inhibe etmiştir.

Benzer şekilde, bifosfonatlarla tedavi edilen osteoporotik hastalarda, özellikle risedronat kullanıldığında periapikal lezyon prevalansında anlamlı bir azalma görülmüştür (62).

\section{Romatoid Artrit}

Romatoid artrit ile apikal periodontitis patobiyolojik açıdan birbirine benzeyen, bağ dokusu ve kemik yıkımı ile karakterize, kronik enflamatuvar hastalıklardır. Ek olarak, her iki hastalığın ilerlemesi, nükleer faktör kB'nin reseptör aktivatörünün aktive edilmesi üzerinden kemik rezorpsiyonunu içermektedir (63). Ayrıca periapikal lezyonlarda bulunan Immunoglobulin G romatoid faktörü ile romatoid hastalık arasında pozitif bir korelasyonun olduğu bildirilmiştir (60). Bir başka olası açıklama da romatoid artrit tedavisinde kullanılan ilaçların romatoid artrit'li hastaları apikal periodontitis'e yatkın hale getiren immünosupresif bir etkiye sahip olmasıdır (64). İlk kez Jalali ve ark. tarafından yapılan kesitsel bir çalışmada, romatoid artrit ile periapikal lezyon prevalansı arasında bir ilişkiye rastlanmadığını, ancak romatoid artrit hastalarındaki ortalama diş sayısının sağlıklı bireylere kıyasla daha az olduğunu bildirmişlerdir (65).

Öte yandan Karataş ve ark. (2020), romatoid artrit hastalarını artan apikal periodontitis prevalansı ile önemli ölçüde ilişsili bulmuştur. Ancak periapikal lezyonlu kök kanal tedavili dişler açısından romatoid artrit ve kontrol grupları arasında anlamlı fark olmadığından, romatoid artrit kanal tedavisine verilen yanıtı etkilememiştir (66). 


\section{HIV (Akut İmmün Yetmezlik Sendromu=AIDS)}

AIDS hastalığının etkeni olarak bilinen İnsan İmmün Yetmezlik Virüsü (HIV) pulpada ve pulpa kaynaklı periradiküler lezyonlarda kolaylıkla tespit edilebilmiştir (67). Geçmişte HIV ile enfekte hastalarda endodontik postoperatif flare-up ve semptomların görüldügüne dair bazı raporlar endișe uyandırmıș olsa da (68), Cok Etkin Antiretroviral Tedavi (Highly Active Antiretroviral Treatment-HAART) sürecinde HIV hastalarında endodontik enfeksiyonların klinik seyrinin değiștiği ve HIV enfeksiyonunun periradiküler lezyonların gelişimine ve onarımına müdahale etmediği gösterilmiştir (69).

\section{Orak Hücreli Anemi}

Orak hücreli anemi, normal hemoglobine $(\mathrm{HbA})$ ait beta-globin genindeki bir nokta mutasyonu nedeniyle ortaya çıkan, $\mathrm{Hb}$ molekülü ( $\mathrm{HbS}$ ) ile sonuçlanan yapısal bir hemoglobinopatidir (70). Uzun süreli hipoksemi durumlarında, HbS polimerize olur ve sonuç olarak orak șeklinde kırmızı kan hücreleri (RBC) ve artmış vasküler endotel adezyonu meydana gelir. Bu durum lokal vazokonstriksiyon ve ağrı atakları gibi sistemik komplikasyonlara neden olabilir ve bu da hayati organlara zarar verebilir (71). Diş hekimliğinde, özellikle mandibulada iskemi veya nekroza neden olarak odontojenik olmayan osteomiyeliti tetikleyebilmektedir (72); endodontide ise pulpa mikrosirkülasyonunun vazooklüzyonu sonucunda, pulpitis (73) ve hatta pulpa nekrozuna yol açabilmektedir (74). Orak hücreli anemi hastalarında meydana gelen vazooklüzif ve hemolitik ataklar sırasında pulpitis ağrısının etiyolojisini tanımlayan bir iskemiye neden olmaktadır. Nekroza yatkınlık, apikal periodontitise yol açan bakteri kontaminasyonu beraberinde getirmektedir (75).

Costa ve ark. (2021) orak hücreli anemi (HbSS genotipi) hastalarında kronu sağlam (çürük, periodontal hastalık veya travma öyküsü olmayan) daimi dişlerdeki bakteri varlığını klinik, görüntüleme ve mikrobiyolojik parametreleri analiz ederek değerlendirmiştir. Prospektif klinik, görüntüleme ve mikrobiyolojik analizler, HbSS hastalarında kronu sağlam olan dişlerde meydana gelen pulpa nekrozu ile bakteri varlığının ilişkili olmadığını göstermiştir (76).

\section{Böbrek Taşı (Nephrolithiasis)}

Pulpa taşı (dentikel) oluşumu açısından böbrek taşlarının varlığı ve pulpa üzerindeki etkileri geçtiğimiz yıllarda birçok araştırma tarafından ele alınmıștır (77). Son olarak 2019 yılında yayınlanan bir meta-analiz raporuna göre, pulpa taşı olgularında böbrek taşı insidansının neredeyse iki kat fazla olduğu ileri sürülmüş̧ür. Bu nedenle pulpa taşları, henüz teşhisi konulmamış böbrek taşlarının habercisi olabileceği gibi, gerçek rolünün belirlenebilmesi için daha fazla çalışmaya ihtiyaç duyulmaktadır (78).

\section{Sonuç}

Endodontinin tıbbi yönünün, endodontik tedavinin teknolojik yanları tarafından gölgede tutulduğu söylenebilir (11). Çoğu endodonti kongrelerinin ana bölümünü teknolojik gelişmelerin oluşturması, endodonti biliminin teknik ve mekanik kısmında yapılan araştırmalara göre biyolojik kısmındaki araştırmaların gölgede kalmasına, yalnızca kök kanal tedavisi için kullanılan döner aletler, güta-perka, operasyon mikroskobu, elektronik apeks bulucu gibi araç ve gereçlerden ibaret olduğu algısına neden olmaktadır. Endodontik tıp, endodontinin biyolojik ve tıbbi yönlerini vurgulayarak, apikal periodontitis ve kök kanal tedavisi ile sistemik hastalıkların periapikal enflamasyon, periapikal iyileșme ve kök kanal tedavisi sonuçları üzerindeki etkilerininin bütüncül bir yaklaşımla incelenmesini sağlayacaktır $(11,12)$. Bu alandaki bilimsel çalışmaların eksikliği, kronik apikal periodontitisli dişlerin ağızda tutulması ile doğabilecek riskleri ve endodontik tedavilerin hasta, doktor ve diş hekimleri için gerçek önemini ve avantajlarını maskeleyebilmektedir (12). Bu nedenle endodontik tıp, periodontal tıp ile benzer yolu izlemeli, endodontik ve sistemik hastalıklar arasındaki bağlantıyı araștırmaya devam etmelidir. Ayrıca, sistemik hastalıklar ve sigara kullanımının, pulpa-periyodonsiyum sağlığı üzerindeki etkilerinin de daha fazla araştırılması gerekmektedir. 


\section{Kaynakça}

[1] Pallasch T], Wahl MJ. Focal infection: new age or ancient history? Endodontic Topics 2003; 4: 32-45.

[2] Khalighinejad N, Aminoshariae MR, Aminoshariae A, et al. Association between systemic diseases and apical periodontitis. J Endod 2016; 42:1427-1434.

[3] Slavena Svetlozarova. Association between Systemic Diseases and Endodontic Treatment OutcomeReview of Literature. Adv Dent \& Oral Health. 2019; 11(5): 555821.

[4] Laukkanen, E, Vehkalahti, MM, Kotiranta, AK. Impact of systemic diseases and tooth-based factors on outcome of root canal treatment. Int Endod J 2019, 52, 1417- 1426.

[5] Nagendrababu, V, Segura-Egea, JJ, Fouad, AF, et al. Association between diabetes and the outcome of root canal treatment in adults: an umbrella review. Int Endod J 2020, 53, 455- 466.

[6] Jakovljevic A, Duncan HF, Nagendrababu V, et al. Association between cardiovascular diseases and apical periodontitis: an umbrella review. Int Endod J 2020, 53, 1374- 1386.

[7] Lim G, Janu U, Chiou LL, et al. Periodontal Health and Systemic Conditions. Dent J (Basel) 2020, $8(4): 130$.

[8] Jepsen S, Caton JG, Albandar JM, et al. Periodontal manifestations of systemic diseases and developmental and acquired conditions: Consensus report of workgroup 3 of the 2017 World Workshop on the Classification of Periodontal and Peri-Implant Diseases and Conditions. J. Periodontol. 2018, 89 (Suppl. 1), S237-S248.

[9] Komine-Aizawa S, Aizawa S, Hayakawa S. Periodontal diseases and adverse pregnancy outcomes. J. Obstet. Gynaecol. Res. 2019, 45, 5-12.

[10]Seymour RA. Is gum disease killing your patient? British Dental Journal 2009, 206:551-2.

[11]Segura-Egea JJ, Martín-González J, Castellanos-Cosano L. Endodontic medicine: connections between apical periodontitis and systemic diseases. Int Endod J 2015, 48.10: 933-51.

[12]Aminoshariae A et al. Association between systemic diseases and endodontic outcome: a systematic review. J Endod 2017, 43.4: 514-9.

[13]Kohsaka T et al. Periapical lesions in rats with streptozotocin-induced diabetes. J Endod 1996, 22.8: 418-21.

[14]Azuma MM et al. Omega 3 fatty acids reduce bone resorption while promoting bone generation in rat apical periodontitis. J Endod 2017, 43.6: 970-6.

[15]Gupta A, Aggarwal V, Mehta N, et al. Diabetes mellitus and the healing of periapical lesions in root filled teeth: a systematic review and meta-analysis. Int Endod J 2020, 53, 1472-1484.

[16]Uğur Aydın Z, Ocak MG, Bayrak S, et al. The effect of type 2 diabetes mellitus on changes in the fractal dimension of periapical lesion in teeth after root canal treatment: a fractal analysis study. Int Endod J 2021, 54(2):181-189.

[17]Segura-Egea JJ, Jiménez-Pinzón A, Ríos-Santos JV et al. High prevalence of apical periodontitis amongst type 2 diabetic patients. Int Endod J. 2005, 38(8): 564-9.

[18]López-López J, Jané-Salas E, Estrugo-Devesa A et al. Periapical and endodontic status of type 2 diabetic patients in Catalonia, Spain: a cross-sectional study. J Endod. 2011; 37(5): 598-601.

[19]Dinç, V. Sağlıklı Bireylerle Tip 2 Diyabetes Mellituslu Bireylerin Periapikal Durumunun ve Endodontik Tedavi Kalitesinin Karşılaştırılması. Uzmanlık Tezi, Isparta Süleyman Demirel Üniversitesi,Diş Hekimliği Fakültesi Endodonti AD. Danışman:Prof. Dr. Ayșe Diljin Keçeci 2016.

[20]Taç, G. Tip II diyabetin farklı tanılara sahip dişlerde endodontik mikrofloraya etkisinin incelenmesi. Doktora Tezi, Isparta Süleyman Demirel Üniversitesi, Sağlık Bilimleri Enstitüsü 2008, Endodonti AD, Danışman:Prof. Dr. Ayșe Diljin Keçeci.

[21]Marotta PS, Fontes TV, Armada L et al. Type 2 diabetes mellitus and the prevalence of apical periodontitis and endodontic treatment in an adult Brazilian population. J Endod. 2012; 38(3): 297300.

[22]Fouad AF, Burleson J. The effect of diabetes mellitus on endodontic treatment outcome: data from an electronic patient record. J Am Dent Assoc. 2003; 134(1): 43-51.

[23]Britto LR, Katz J, Guelmann M et al. Periradicular radiographic assessment in diabetic and control individuals. Oral Surg Oral Med Oral Pathol Oral Radiol Endod. 2003; 96(4): 449-52.

[24]Tibúrcio-Machado CD, Bello MC, Maier J et al. Influence of diabetes in the development of apical periodontitis: a critical literature review of human studies. J Endod. 2017; 43(3): 370-6. 
[25]Segura-Egea JJ, Martín-González J, Cabanillas-Balsera D et al. Association between diabetes and the prevalence of radiolucent periapical lesions in root-filled teeth: systematic review and meta-analysis. Clin Oral Investig. 2016; 20(6): 1133-41.

[26]Arya S, Duhan J, Tewari S et al. Healing of apical periodontitis after nonsurgical treatment in patients with type 2 diabetes. J Endod 2017; 43: 1623-7.

[27]Sarmento EB, Gomes CC, Pires FR, et al. Immunoexpression of bone resorption biomarkers in apical periodontitis in diabetics and normoglycaemics. Int Endod J 2020, 53, 1025- 1032, 2020.

[28]Schulze A, Schönauer M, Busse M. Sudden improvement of insulin sensitivity related to an endodontic treatment. J Periodontol 2007; 78.12: 2380-2384.

[29]Saghiri MA, Aminsobhani M, Gutmann JL, et al. Effect of Diabetes on Rotary Instrumentation of Dentin. J Endod 2021, 47(8): 1301-1307.

[30]Maat MP, Kluft C. Determinants of C-reactive protein concentration in blood. Italian Heart Journal 2001; 2: 189-95.

[31]Segura-Egea JJ, Jimenez-Moreno E, Calvo-Monroy C et al. Hypertension and dental periapical condition. J Endod. 2010; 36(11): 1800-4.

[32]Pasqualini D, Bergandi L, Palumbo L et al. Association among oral health, apical periodontitis, CD14 polymorphisms, and coronary heart disease in middle-aged adults. J Endod. 2012; 38(12): 1570-7.

[33] Cosme-Silva, Leopoldo, et al. Hypertension affects the biocompatibility and biomineralization of MTA, High-plasticity MTA, and Biodentine. Braz Oral Res 2019; 33.

[34]Abdolsamadi HR, Vahedi M, Esmaelli $F$ et al. Serum interleukin- 6 as a serologic marker of chronic periapical lesions: a case-control study. J Dent Res, Dental Clinics, Dental Prospects 2008; 2: 43-7.

[35]Proctor ME, Turner DW, Kaminski EJ et al. Determination and relationship of C-reactive protein in human dental pulps and in serum. J Endod 1991; 17: 265-270.

[36]Márton I, Kiss C, Balla G et al. Acute phase proteins in patients with chronic periapical granuloma before and after surgical treatment. Oral Microbiol Immunol, 1988; 3.2: 95-96.

[37]Ren, Yan-Fang; Malmstrom, Hans S. Rapid quantitative determination of C-reactive protein at chair side in dental emergency patients. Oral Surg Oral Med Oral Pathol Oral Radiol Endod. 2007; 104.1: 4955.

[38]Vidal F, Fontes TV, Marques TV et al. Association between apical periodontitis lesions and plasmatic levels of C-reactive protein, interleukin 6 and fibrinogen in hypertensive patients Int Endod J. 2016: 49.12: 1107-1115.

[39]Joshipura KJ, Wand HC, Merchant AT et al. Periodontal disease and biomarkers related to cardiovascular disease. J Dent Res. 2004; 83(2): 151-5.

[40]Messing M, Souza LC, Cavalla F et al. Investigating Potential Correlations between Endodontic Pathology and Cardiovascular Diseases Using Epidemiological and Genetic Approaches. J Endod. 2019; 45.2: 104-110.

[41]Pan B, Jin X, Jun L, et al. The relationship between smoking and stroke: a meta-analysis. Medicine 2019, 98, e14872.

[42]Pinto KP, Ferreira CM, Maia LC, et al. Does tobacco smoking predispose to apical periodontitis and endodontic treatment need? A systematic review and meta-analysis. Int Endod J 2020, 53, 1068-83.

[43]Bis JC, Heckbert SR, Smith NL et al. Variation in inflammation-related genes and risk of incident nonfatal myocardial infarction or ischemic stroke. Atherosclerosis 2008, 198, 166-73.

[44]Bhatti JS, Vijayvergiya R, Singh B, et al. Genetic susceptibility of glutathione S-transferase genes (GSTM1/ T1 and P1) to coronary artery disease in Asian Indians. Annals of Human Genetics 2018; 82, 448-56.

[45]Salles AG, Antunes LAA, Ku€chler EC, Antunes LS. Association between apical periodontitis and interleukin gene polymorphisms: a systematic review and meta-analysis. J Endod 2018; 44, 355-62.

[46]Cintra LTA, Estrela C, Azuma MM, et al. Endodontic medicine: interrelationships among api- cal periodontitis, systemic disorders, and tissue responses of dental materials. Brazilian Oral Research 2018; 32, 66-81.

[47]Ren H, Du M. Role of maternal periodontitis in preterm birth. Frontiers in Immunology 2017; 8:139.

[48]Bain JL, Lester SR, Henry WD et al. Effects of induced periapical abscesses on rat pregnancy outcomes. Archives of Oral Biology 2009; 54: 162-71.

[49]Ao M, Miyauchi M, Furusho H et al. Dental infection of Porphyromonas gingivalis induces preterm birth in mice. PLoS One 2015; 10: e0137249. 
[50]Tsosura TVS, Chiba FY, Mattera MSLC et al. Maternal apical periodontitis is associated with insulin resistance in adult offspring. Int Endod J 2019.

[51]Alam Q, Alam MZ, Mushtaq G et al. Inflammatory Process in Alzheimer's and Parkinson's Diseases: Central Role of Cytokines. Current Pharmaceutical Design 2016; 22: 541-8.

[52]Florencio-Silva R, Sasso GRS, Sasso-Cerri E et al. Effects of estrogen status in osteocyte autophagy and its relation to osteocyte viability in alveolar process of ovariectomized rats. Biomedicine \& Pharmacotherapy 2018; 98: 406-415.

[53]Bobetsis YA, Graziani F, Gürsoy M \& Madianos PN. Periodontal disease and adverse pregnancy outcomes. Periodontology 2000, 83, 154-174.

[54]Madianos PN, Bobetsis YA \& Offenbacher S. Adverse pregnancy outcomes (APOs) and periodontal disease: pathogenic mechanisms. Journal of Clinical Periodontology 2013, 40, S170-S180.

[55]Sgolastra F, Petrucci A, Severino, et al. Relationship between periodontitis and pre-eclampsia: a metaanalysis. PLoS One 2013, 8, e71387.

[56]Corbella S, Taschieri S, Del Fabbro M., et al. Adverse pregnancy outcomes and periodon- titis: a systematic review and meta-analysis exploring potential association. Quintessence International 2016, 47, 193-204.

[57]Jakovljevic A, Nikolic N, Jacimovic J et al. Prevalence of apical periodontitis and conventional nonsurgical root canal treatment in general adult population: an updated systematic review and meta-analysis of cross-sectional studies published between 2012 and 2020. J Endod 2020, 46, 137186.e8.

[58]Harjunmaa U, Järnstedt J, Alho L, et al. Association between maternal dental periapical infections and pregnancy outcomes: results from a cross- sectional study in Malawi. Tropical Medicine \& International Health 2015, 20, 1549-1558.

[59]Romualdo PC, Lucisano MP, Paula-Silva FWG et al. Ovariectomy Exacerbates Apical Periodontitis in Rats with an Increase in Expression of Proinflammatory Cytokines and Matrix Metalloproteinases. J Endod 2018; 44: 780-5.

[60]Malmström M. Immunoglobulin classes IgG, IgM, IgA and complement component C3 in dental periapical lesions of patients with rheumatoid disease. Scand J Rheumatol 1975; 4: 57-64.

[61]Silva RAB, Sousa-Pereira AP, Lucisano MP, et al. Alendronate inhibits osteocyte apoptosis and inflammation via IL-6, inhibiting bone resorption in periapical lesions of ovariectomized rats. Int Endod J 2021; 53,84-96.

[62]Katz J, Rotstein I. Prevalence of Periapical Lesions in Patients with Osteoporosis. J Endod 2020, 47(2), 234-238.

[63]Cotti E, Schirru E, Acquas E, Usai P. An overview on biologic medications and their possible role in apical periodontitis. J Endod 2014; 40(12):1902-11.

[64]Koczan D, Drynda S, Hecker M, et al. Molecular discrimination of responders and nonresponders to anti-TNF alpha therapy in rheumatoid arthritis by etanercept. Arthritis Res Ther 2008; 10(3): R50.

[65]Jalali P, Hasselgren G. Endodontic inter-appointment flare-ups: An example of chaos? Dent Hypotheses 2015; 6: 44-8.

[66]Karataş E, Kul A, Tepecik E. Association between Rheumatoid Arthritis and Apical Periodontitis: A Cross-sectional Study. Eur Endod J 2020; 2: 155-8.

[67]Elkins DA, Torabinejad M, Schmidt RE et al. Polymerase chain reaction detection of human immunodeficiency virus DNA in human periradicular lesions. J Endod 1994; 20.8: 386-388.

[68]Gerner NW, Hurlen B, Dobloug J et al. Endodontic treatment and immunopathology of periapical granuloma in an AIDS patient. Endod Dent Traumatol 1988; 4: 127-131.

[69]Fontes TV; Marques FV, Gonçalves LS. Endodontic infection in HIV-infected individuals: An overview. Endodontic Practice Today, 2015; 9.1.

[70]Ouies HS, Casamassimo OS, da Fonseca M. Sickle cell anemia: a review for the pediatric dentist. Pediatr Dent 2007; 29: 159-69.

[71] Hebbel RP, Vercellotti GM, Nath KA. A systems biology consideration of the vasculopathy of sickle cell anemia: the need for multi-modality chemo-prophylaxis. Cardiovasc Hematol Disord Drug Targets 2009; 9: 271-92.

[72]Al-Jafar H, Dashti H, Al-Haddad SJ et al. Dental alterations in sickle cell disease. J Dent Oral Care Med 2016; 2: 203. 
[73]Vgontzas A, Charleston IVL, Robbins MS. Headache and facial pain in sickle cell disease. Curr Pain Headache Rep 2016; 20: 1-10.

[74] Costa CPS, Thomaz EBA, Souza SFC. Association between sickle cell anemia and pulp necrosis. J Endod 2013; 39: 177-81.

[75]Koffi-Gnagne Y, Djolé SX, Avoaka-Boni MC, et al. Multidisciplinary management of homozygous sickle cell patients: Dental treatment pathologies and needs. Turk Endod J 2019;4(1):6-10.

[76]Costa CPS, Silva M, Lima-Neto GL et al. Is there bacterial infection in intact crowns teeth and pulp necrosis of sickle-cell anaemia patients? A case series study nested in a cohort. Int Endod J 2021; 54.

[77]Movahhedian N, Haghnegahdar A, Owji F. How the prevalence of pulp stone in a population predicts the risk for kidney stone. Iran Endod J 2018; 13: 246-50.

[78]Gabardo MCL, Wambier LM, Rocha JS et al. Association between Pulp Stones and Kidney Stones: A Systematic Review and Meta-analysis. J Endod. 2019 Sep;45(9):1099-1105. 